\title{
Keeping Our Nation's Mathematics Teachers
}

\author{
Carol Curtis \\ Mathematics Department, Fresno City College, 1101 East University Avenue, Fresno, CA 93741, USA \\ Correspondence should be addressed to Carol Curtis, carol.curtis@fresnocitycollege.edu
}

Received 21 October 2012; Accepted 8 November 2012

Academic Editors: M. F. Cerda and M. Reis

Copyright ( 2012 Carol Curtis. This is an open access article distributed under the Creative Commons Attribution License, which permits unrestricted use, distribution, and reproduction in any medium, provided the original work is properly cited.

\begin{abstract}
Teacher retention has been an issue that has influenced education for many years. The purpose of this research was to uncover the factors that influence a mathematics teacher's decision to leave the teaching profession. This study compared teachers' responses by regions of the country, as well as responses between middle school and high school mathematics teachers. Findings from the study indicate an alarmingly high rate of teachers who will be leaving the teaching field for reasons other than retirement. The role of administrators in teacher retention is significant, and implications from the research suggest that an increase in administrator training could play a major role in keeping our nation's mathematics teachers in the classroom.
\end{abstract}

\section{Introduction}

Staffing the nation's schools with well-qualified teachers has been an issue in elementary and secondary education for a long time. As far back as 1957, studies reported that teacher turnover was the most serious problem facing the schools [1]. In 1973, researchers examined the relationship between teacher migration and students' socio-economic status, and in the 1980s incidents of out-of-field teaching were examined.

Researchers have taken a special interest in mathematics and science teachers because of the need for individuals entering the workforce with advanced knowledge in these subject areas [2]. In the past decade, widespread mathematics teacher staffing problems continue to exist nationwide. Some research findings suggest that the current and continuing shortage of mathematics teachers is due to increases in teacher retirements and student enrollments [3]. However, as more and with more research is compiled, the factors that affect teacher attrition and retention would appear to be varied.

In the past 20 years, the overall number of subject-area teachers at the middle and secondary levels has increased by $50 \%$ [4]. The fastest rate of increase in mathematics and science teachers took place in the 1990s. The increase during this decade was primarily due to states increasing mathematics course requirements for high school graduation. Nationally, between 1987 and 2008, the number of high school students taking courses in mathematics increased by $69 \%$. Over the same time period, the number of teachers with mathematics degrees increased by $74 \%$. With the increase in enrollment, graduation requirement changes, and with more students taking mathematics courses, the market for the employment of high school mathematics teachers has risen. However, the new supply of mathematics teachers has more than kept pace with increased retirements and student enrollments [3]. In analyzing the teaching market, school districts must consider various factors. Because teacher salaries are the largest item in school district budgets, the cost of teacher salaries is a major consideration.

Another current consideration for school districts is the graying of the teacher workforce. As of 2008, the age distribution of teachers is two peaked, with large proportions of teachers at both ends of the age spectrum. Another recent trend in the teaching workforce is the increase in teacher turnover. The turnover includes both teachers who move between schools as well as teachers who leave the profession altogether. Teacher turnover rates have increased by $28 \%$ between 1995 and 2010. Turnover rates among minority teachers are significantly greater than those for white teachers, and turnover rates are not equally distributed across states, regions, and school districts [4]. 


\section{Purpose of the Study}

The purpose of this study was to gain an insight into which factors contribute to a mathematics teacher's decision to stay in or to leave the teaching profession (i.e., teacher retention or teacher attrition, resp.). This study compared teachers' responses by region of the country, as well as responses between middle school and high school teachers of mathematics. Surveys of mathematics teachers nationwide were administered and analyzed. Demographic information was collected and teachers were asked to respond to statements regarding their working conditions and administrative support.

Some previous studies have examined factors in the retention of the general teacher population, while other studies have separated teachers by field (e.g., [3]). This study made a unique contribution to the research in the area of mathematics teacher attrition because it focused specifically upon mathematics teachers at the middle and high school levels, and responses were drawn from current mathematics teachers nationwide. Rather than examining data collected through other sources or studies, this study has drawn and analyzed responses from a random sample of mathematics teachers throughout the United States with the specific purpose of uncovering patterns and differences in attrition. While some past studies were centered upon specific localized groups of teachers in a given state or at particular types of schools, this study compared responses of teachers from the general population of all mathematics teachers from varied backgrounds and from different regions of the country. Additionally, the comparison between responses of middle school and high school mathematics teachers made this study unique to previous studies.

\section{Theoretical Framework}

The American school system is a unique organization composed of various components operating at the federal, state, and local levels. Research conducted on the organization of schooling began in the 1970s [5]. Organization theorists at that time described schools as "loosely coupled systems," "organized anarchies," and "decoupled organizations." Theorists such as Max Weber had previously stated that schools could be defined as a bureaucracy and "the methodological creation of systems of impersonal rules" [5, page 30]. While Weber appreciated the efficiency of a bureaucracy, he also recognized the possible rigidity and inflexibility of a bureaucracy. Another leading theorist, Dewey, noted the incompatibility between bureaucracy and the work of teachers [6]. Education studies by Dewey [6] and Durkheim [7] held that a major purpose of schools was in their social function. They argued that schools have the same function as religion, and that is to pass on the morals of society.

In contrast to Weber, institutional theorists Meyer and Scott [8] viewed schools as weak and ineffective organizations that have little capacity to produce a useful effect in measuring student performance. The consensus of the research community in the last 40 years has been that schools are loosely structured, uncontrolled, and undercoordinated.
Critics have blamed schools and teachers for a multitude of societal problems [5].

Using these theories as a background for understanding the role of schools and teachers in our society, the framework for this study was constructed. The decision of an individual to pursue the field of teaching is one that is founded upon a variety of personal choices. Once an individual becomes a teacher and assumes the role which education and society has defined, the decision of whether or not to remain in the profession is based upon a variety of factors. This study explored relevant literature in seeking which factors were significant in teacher attrition prior to formulating the research questions.

\section{Research Questions}

The research questions for this study were as follows.

(1) Are teacher demographic factors related to mathematics teacher retention?

(2) Are classroom control factors related to mathematics teacher retention?

(3) Is administrator support related to mathematics teacher retention?

(4) Are there differences in retention rates between middle school and high school mathematics teachers?

\section{Literature Review}

All children have the right to learn and should have access to a qualified teacher. Disparities exist in our schools, and many children attend schools housed in poor facilities, without textbooks and without a qualified teacher [9]. Teacher shortages are not new. In the past 50 years, there have often been fewer teachers available than needed, forcing policy makers to increase recruitment efforts and issue temporary credentials to those without proper qualifications [10]. Specifically, mathematics and science teachers are in high demand, and many state and federal programs such as the Science Mathematics Initiative have been initiated in an attempt to meet the need. In schools with large numbers of minority students and/or impoverished students, mathematics and science courses are often taught by teachers who do not have adequate background or teaching skills in the subject matter [11].

Increasing recruitment efforts is one issue that must be dealt with. Teacher recruitment is an important challenge, but Ingersoll [12] has made the strong claim that an even greater concern is teacher retention. Thus, it is important to understand why teachers leave the profession. Results of ongoing research find that "critical problems in the teaching and learning environment are literally driving teachers from the classroom" [13, page 1]. Recruitment, hiring, and replacement of teachers are factors that are costing California alone more than $\$ 455$ million each year [13].

5.1. Teacher Demographics. Teacher attrition is a significant issue that has far-reaching effects in the public school system. 
The United States Department of Education [14] reports that almost a quarter of entering public school teachers leave teaching within their first 3 years. The rates are even higher in schools with low academic achievement.

Gender, age, ethnicity, and experience are also indicators of who goes into teaching and who remains in teaching. Attrition rates for young and new teachers are higher than those of older and more experienced teachers [15]. Women tend to have higher attrition rates than men, and minority teachers tend to have lower attrition rates than nonminority teachers.

5.2. Classroom Control. The environment in which a teacher works is unique to that of most other professionals. According to Ingersoll [5], the teacher's role is social as well as instructional. The social role involves parenting as well as dealing with "unusual" clients. Unlike other professionals, the teacher cannot choose the client (student), and there is little agreement in education as to what the final product should be [5]. The structure of the school can range from a centralized to a decentralized system. The level of autonomy given to a teacher fluctuates by school site and by district. Even within a given school, the level of input a teacher has in decision-making can vary depending upon the type of decision. In most cases, teachers tend to have more control over academic instruction and less control over socialization issues. Teacher retention rates are likely to correlate with the level and type of decisions that a teacher controls.

There is a direct relationship between the level of control teachers have in social and instructional decisions and the probability of turnover [5]. Ingersoll defines instructional decisions as those involving the teaching of concepts in the classroom, course objectives, and student evaluation standards. Social decisions are defined as those involving scheduling, class size, hiring, and budget. Higher levels of control in social decision-making indicate lower levels of teacher turnover. The level of decision-making in academic instruction does not appear to have a significant impact upon turnover rates.

Further research concurred with Ingersoll's findings. Because 1st year teachers have a higher risk of quitting teaching than any other teacher, it is important to understand the possible factors involved [16]. Almost half of beginning teachers leave teaching in their first 5 years. Results of Liu's research demonstrated that the higher the level of teacher participation in school decision-making, the lower the turnover rate. Liu [16] stated "A school culture characterized by strong teacher influence may well nurture a bond between 1 st year teachers and their schools because 1st year teachers can foresee increased professional opportunities for playing leadership roles in their organizations" (page 13).

Recruiting the right teachers with the right preparation is important to ensure that students are taught well. However, the Center for Teaching Quality [17] attempted to show that the right working conditions must also be in place for teachers to teach effectively and for students to learn. Typically when teachers' working conditions are discussed, the topics that come to the forefront are salaries, benefits, and class size. Researchers focused upon a range of working conditions, such as time, facilities, resources, empowerment, school leadership, and professional development. Through surveys administered to over 250,000 teachers, several trends were noted. In relationship to working conditions, responses showed that teachers who intended to leave their schools had serious concerns about their lack of empowerment, poor school leadership, and low levels of trust on their campuses.

The working environment of the teacher can be emotionally exhausting when dealing with student behavior. Tsouloupas et al. [18] collected data through a survey from 610 teachers at all grade levels. The results of the survey showed a significant relationship between emotional exhaustion and turnover intentions. Emotion regulation strategies (cognitive, reappraisal, and expressive suppression) were used with participants. Despite these strategies to cope with various workplace-caused emotions, the teachers with higher emotional exhaustion had higher turnover intentions. The teachers' perceptions of student misbehavior also had a considerable indirect effect on teacher turnover intentions.

Working conditions at a school can have different effects upon teachers depending upon the level of classroom experience [19]. Studying the effects of administrative support, classroom control, and behavioral climate on teachers' decisions to quit teaching or switch schools, Kukla-Acevedo's study concluded that workplace conditions were strongly related to the mobility decisions of 1 st year teachers. Experienced teachers were not as strongly influenced by workplace conditions.

In a qualitative study, Buchanan [20] conducted semistructured interviews with 22 people who had left teaching to take up other careers. Some of the participants had taught just a few months, while others had taught more than 20 years. The participants were chosen because of the fact that they could make comparisons between teaching and another career. Comments by participants cited lack of air conditioning in schools, lack of support from staff, and lack of control in the pace of the teaching job as negative factors in classroom teaching. Most former teachers were disillusioned by the all-consuming nature of the teaching career. Although many of the participants had demanding second careers, most were willing to sacrifice some of the perks of teaching for the independence afforded them in their current jobs.

5.3. Administrator Support. The beginning teacher faces many challenges. These challenges can seem overwhelming when the new teacher must deal with the working environment of the school, student, and parent issues, as well as curriculum and lesson planning. The level of administrative support can make a tremendous impact upon the success and well-being of the novice teacher. Researchers have studied the level of support received in relationship to teacher retention.

A survey of superintendents in Illinois, Indiana, Iowa, Michigan, Minnesota, Ohio, and Wisconsin sought to gain information on strategies implemented to attract and retain teachers, and about how effective those strategies were [21]. All 3,506 superintendents in these midwestern states were sent surveys with 2,413 of them returned. 
The survey was divided into three sections: new teacher support programs, retention strategies, and recruitment strategies. Effective retention strategies included increasing teacher salaries, restructuring schools to make them smaller, and improving staff development. Recommendations made from the research involved encouraging districts to adopt a new teacher support program, adopt policies that include teachers in decision making, make scheduling changes to increase collaboration between teachers, recruit "homegrown" teachers, partner with neighboring districts to implement strategies, keep salaries competitive, and team with institutions of higher education.

The role of the site principal is a critical one in regards to new teacher success and retention. The CharlotteMecklenburg Schools (CMS) were the focus of a study to identify principal traits and success strategies used by the principals in retaining teachers [22]. Between 15\% and 20\% of teachers at CMS were leaving their classrooms each year. The rate was even higher for teachers with less than 3-year experience. The Charlotte Advocates for Education (CAE) found that the teachers cited working conditions as the primary reason for leaving. The leadership of the principal was often the key component in the positive working environment. Using predetermined criteria, 20 principals were identified and surveyed. The results revealed some common themes, and focus groups were used to explore the results in a more in-depth manner. The traits of the principals most successful in retaining teachers were self-motivation, problem-solving ability, and risk-taking. They were seen as visionary leaders and were committed and passionate about their profession. The most important strategies principals used in achieving high teacher retention rates involved building appropriate relationships with staff, supporting teachers, including teachers in decision-making, empowering staff, providing teachers opportunities to grow in their profession, being accessible to teachers, and providing individual and team structured planning time.

The role played by the principal in daily operations of the school is very apparent. The impact the principal has upon student achievement and teacher retention is one in which much remains unknown [23]. The change in the leadership at a school can have a far-reaching effect. Miller investigated the causes and consequences of principal turnover in relationship to student achievement and teacher turnover. Using public school data in North Carolina, the timing of principal transition was recorded and compared with student achievement data and teacher turnover statistics. More than half of the principals in the study left their schools within 4 years. The variation across schools in the number of principal transitions was substantial. Some schools had a single principal while others had as many as seven principals. The findings of the study revealed that on average there were no changes in teacher retention in the years prior to the transition of the principal. However, a higher than usual percentage of teachers leave the school at the same time the principal leaves and teacher retention remains low after the 1st year of a new principal. In schools with no principal transition, there is a positive correlation between teacher retention and the growth of test scores.
The high attrition rate of new teachers in a school district of a southeastern state prompted an exploration of the role that the principal plays in teacher retention [24]. The large school district served 32,000 students in 45 schools. Data were collected over 2 years by using the 12 schools in the district with the lowest attrition rates of beginning teachers. In interviews with the school principals, common retention strategies surfaced. They consistently felt that their role was to advocate, protect, and mentor new teachers. They reported that they visited their classrooms often, talked with them regularly, and stressed the importance of being visible. The principals had several ideas about why they felt teachers left the profession. Some of the reasons were lack of support, an unrealistic view of what teaching is about, not feeling as if they are being heard, or feeling overwhelmed.

The question of teachers' perceptions of how principals can affect their job satisfaction was explored by interviewing veteran teachers over a period of 3 months [25]. Participants answered questions about their level of job satisfaction, perceptions of their principals' leadership styles, and reasons why they continue to teach. Common characteristics of responses revealed that teachers appreciate the encouragement of positive relationships between teachers and students and professionalism among faculty, staff, and administration. The teachers also appreciated positive feedback and accessibility from the principals.

\section{Methodology}

The sample for this study was one of voluntary response, meaning that the individual had the option of whether or not to participate. Collecting data from every middle and high school mathematics teacher in the nation would entail a lengthy and costly procedure and would not be feasible. A nationwide sample of mathematics teachers from various regions, schools, and grade levels was randomly selected to participate in the study.

The sample was drawn from a database of middle and high school mathematics teachers across the United States. The sample numbered 5000 teachers, randomly selected with the assistance of a national marketing corporation. Market data retrieval (MDR) selected the names for the random sample. MDR advertised a bank of 84,709 middle school mathematics teachers' names and contacts, as well as 132,252 names and contacts of high school mathematics teachers. From this pool of teachers, 2,000 middle school and 3,000 high school mathematics teachers were selected to participate in the study.

Surveys and a cover letter were mailed via US mail to mathematics teachers at their school addresses nationwide. A code number was placed on each survey for tracking purposes. A stamped, self-addressed envelope was included with each survey for the return convenience of the participant.

Survey questions (see the appendix) used a combination of 4-point Likert scale, multimodal, and free response questions. Demographic questions were placed at the end of the survey. Selected questions were taken from the schools and staffing survey (SASS) [26]. Reliability for the SASS was 
TABLE 1: Number of respondents by age.

\begin{tabular}{lcc}
\hline Age & $f$ & $\%$ \\
\hline Less than 25 & 52 & 3.3 \\
$26-35$ & 408 & 26.0 \\
$36-45$ & 420 & 26.7 \\
$46-55$ & 364 & 23.2 \\
$56-65$ & 272 & 17.3 \\
$66+$ & 23 & 1.5 \\
No response & 32 & 2.0 \\
\hline Total & 1571 & 100.0 \\
\hline
\end{tabular}

reported to be .630. The SASS questions chosen for this study were those that most closely aligned with the research questions.

\section{Results}

The dependent variable of attrition was tested against multiple independent variables. The dependence among the various demographic factors was measured against the participants' intention to remain in the teaching profession by means of a chi-square test. Chi-square tests of independence were conducted for variables of age, ethnicity, years of teaching, and region with the decision to leave or stay.

A one-way analysis of variance (ANOVA) was conducted to test the significance of the means of the responses for the composite variables of classroom control and administrative support, in relationship to the intention to leave the teaching profession. An additional ANOVA was conducted to test the significance of the means of the individual components of the composite variable of classroom control in relationship to the intention to leave the teaching profession.

A multivariate analysis of variance (MANOVA) was conducted to test the mean responses to the independent variables against the decision to leave or stay and against the additional component of whether the respondent teaches a middle school or high school. Throughout the analysis of the data, participants' responses were coded in order to retain confidentiality.

7.1. Demographics. Out of 5000 surveys mailed in October 2010,1571 were returned for a response rate of $31 \%$. Approximately $38 \%$ of the respondents were male and $62 \%$ were female. Respondent ages ranged from 23 to 77 with a mean age of 42.5. The ages of the participants were classified into six subgroups and are displayed in Table 1. Ethnicities of the participants are displayed in Table 2, and participants' years of teaching experience are displayed in Table 3.

Surveys were mailed to teachers in all 50 states and the District of Columbia. Once the surveys were returned, participants were categorized into one of the nine regions as identified by the United States Census Bureau [27]. Participant regions are shown in Table 4.

When asked about their intention to leave the teaching profession, 520 teachers $(33.1 \%)$ stated that they planned to leave in the next five years, while 1051 teachers $(66.9 \%)$ stated
TABle 2: Number of respondents by ethnicity.

\begin{tabular}{lcc}
\hline Ethnicity & $f$ & $\%$ \\
\hline African American & 64 & 4.1 \\
Asian & 29 & 1.8 \\
Latino & 64 & 4.1 \\
White & 1365 & 86.9 \\
Other & 28 & 1.8 \\
No response & 21 & 1.3 \\
\hline Total & 1571 & 100.0 \\
\hline
\end{tabular}

TABLE 3: Number of respondents by teaching experience.

\begin{tabular}{lcc}
\hline Years of experience & $f$ & $\%$ \\
\hline 5 or less & 329 & 20.9 \\
$6-10$ & 393 & 25.0 \\
$11-20$ & 517 & 32.9 \\
More than 20 & 324 & 20.6 \\
No response & 8 & .5 \\
\hline Total & 1571 & 100.0 \\
\hline
\end{tabular}

TABLE 4: Number of respondents by region.

\begin{tabular}{lcc}
\hline Region & $f$ & $\%$ \\
\hline New England & 80 & 5.1 \\
Mid-Atlantic & 223 & 14.2 \\
East North Central & 273 & 17.4 \\
West North Central & 140 & 8.9 \\
South Atlantic & 248 & 15.8 \\
East South Central & 83 & 5.3 \\
West South Central & 195 & 12.4 \\
Mountain & 132 & 8.4 \\
Pacific & 197 & 12.5 \\
\hline Total & 1571 & 100.0 \\
\hline
\end{tabular}

that they planned to remain indefinitely or until retirement. Statistical results indicated that gender was not significantly related to attrition, while the decision to leave or stay in the profession was significantly dependent upon age $\left(\chi^{2}=\right.$ 61.023 , df $=5, P<.001)$. The highest percentage of those leaving was aged $26-35$. Within that age group, 36.2\% intended to leave teaching in the near future. Results are displayed in Table 5.

Results of the study indicated that the decision to leave teaching was significantly dependent on ethnicity $\left(\chi^{2}=\right.$ 10.104 , $\mathrm{df}=4, P=.039$ ). Minority teachers are leaving the teaching profession at a higher rate than white teachers. While African American teachers accounted for $4.1 \%$ of the total respondents, they accounted for $4.5 \%$ of those leaving teaching. Asian teachers accounted for $1.9 \%$ of the total respondents, but accounted for $2.1 \%$ of those who were leaving. Latino teachers were $4.1 \%$ of the respondents, but accounted for $5.1 \%$ of those who were leaving. These results are displayed in Table 6.

Attrition is significantly dependent upon the number of years of teaching $\left(\chi^{2}=49.880, \mathrm{df}=3, P<.001\right)$. Teachers 
TABLE 5: Frequencies and percentages by age and leavers/stayers.

\begin{tabular}{|c|c|c|c|c|c|c|c|c|}
\hline \multirow{2}{*}{ Age } & \multicolumn{2}{|c|}{ Leaving } & \multirow{2}{*}{$\%$ within leave/stay } & \multicolumn{2}{|c|}{ Staying } & \multirow{2}{*}{$\%$ within leave/stay } & \multicolumn{2}{|c|}{ Total } \\
\hline & $f$ & $\%$ & & $f$ & $\%$ & & $f$ & $\%$ \\
\hline$<26$ & 26 & 1.7 & 5.1 & 26 & .7 & 2.5 & 52 & 3.4 \\
\hline $26-35$ & 186 & 12.1 & 36.2 & 222 & 14.4 & 21.7 & 408 & 26.5 \\
\hline $36-45$ & 135 & 8.8 & 26.3 & 285 & 18.5 & 27.8 & 420 & 27.3 \\
\hline $46-55$ & 109 & 7.1 & 21.2 & 255 & 16.6 & 24.9 & 364 & 23.7 \\
\hline $56-65$ & 53 & 3.4 & 10.3 & 219 & 14.2 & 21.4 & 272 & 17.7 \\
\hline$>66$ & 5 & .3 & 1.0 & 18 & 1.2 & 1.8 & 23 & 1.5 \\
\hline Total & 514 & 33.4 & 100.0 & 1025 & 66.6 & 100.0 & 1539 & 100.0 \\
\hline
\end{tabular}

TABLE 6: Frequencies and percentages by ethnicity and leavers/stayers.

\begin{tabular}{|c|c|c|c|c|c|c|c|c|}
\hline \multirow{2}{*}{ Ethnicity } & \multicolumn{2}{|c|}{ Leaving } & \multirow{2}{*}{$\%$ within leave/stay } & \multicolumn{2}{|c|}{ Staying } & \multirow{2}{*}{$\%$ within leave/stay } & \multicolumn{2}{|c|}{ Total } \\
\hline & $f$ & $\%$ & & $f$ & $\%$ & & $f$ & $\%$ \\
\hline African American & 23 & 1.5 & 4.5 & 41 & 2.6 & 4.0 & 64 & 4.1 \\
\hline Asian & 11 & .7 & 2.1 & 18 & 1.2 & 1.7 & 29 & 1.9 \\
\hline Latino & 26 & 1.7 & 5.1 & 38 & 2.5 & 3.7 & 64 & 4.1 \\
\hline White & 438 & 28.3 & 85.2 & 927 & 59.8 & 89.5 & 1365 & 88.1 \\
\hline Other & 16 & 1.0 & 3.1 & 12 & .8 & 1.2 & 28 & 1.8 \\
\hline Total & 514 & 33.2 & 100.0 & 1036 & 66.8 & 100.0 & 1550 & 100.0 \\
\hline
\end{tabular}

with less than 6 years of teaching and teachers with 6-10 years of teaching are leaving the profession at a higher rate than teachers in any other age group. These two age groups combined to make up over half of the teachers who declared their intention to leave the field. Results are displayed in Table 7.

Attrition is significantly dependent upon the region of the country $\left(\chi^{2}=30.802\right.$, df $\left.=8, P<.001\right)$. The highest percentage of teachers who are staying are in the East North Central region, while the highest percentage of teachers leaving are those in the South Atlantic and West South Central regions of the United States. Table 8 displays these results.

7.2. Classroom Control. To assess teachers' perceptions of their level of control in the classroom setting, responses from six survey questions were compiled to form a composite variable. Teachers were asked to gauge their level of control in selecting textbooks, selecting teaching topics, selecting teaching techniques, evaluating students, disciplining students, and the amount of homework assigned. There was a significant difference in the mean responses concerning classroom control $(F=10.831$, df $=1, P<.001)$ between those who are leaving and those who are staying in the teaching profession. With further analysis, individual classroom control components were tested for significance. Significant results were found for control in selecting textbooks $(F=$ 6.958, $\mathrm{df}=1, P=.008)$, control in selecting teaching topics $(F=6.598, \mathrm{df}=1, P=.010)$, and control in selecting teaching techniques $(F=4.161$, $\mathrm{df}=1, P=.042)$.

These results (Table 9 ) indicate that teachers' perceptions of their level of classroom control are a significant factor in their decision to leave the profession. The most important factors in their decisions appear to be their autonomy to select their own textbooks, teaching topics, and teaching techniques.

7.3. Administrative Support. Teachers were asked to assess their perception of the level of administrative support they were given. There was a significant difference in the mean responses concerning the administrations' behavior toward the staff being supportive and encouraging $(F=17.079$, df $=1, P<.001)$ between those who were leaving and those who were staying in the teaching profession. This result indicated that when teachers feel positive support from their administration, they are more likely to remain in the teaching field.

7.4. Middle School versus High School. After testing multiple variables in relationship to teacher retention, the final research question sought to determine if there were differences in these variables in teacher attrition when comparing middle school and high school mathematics teachers. The analysis revealed that while there were significant differences in responses from the two groups in several areas, there was no significant difference in relationship to teacher attrition. This finding implies that both middle school and high school mathematics teachers are leaving the teaching profession at about the same rate.

There was a significant difference between middle school and high school teachers in response to gender, ethnicity, and region. In terms of gender, if the respondent was a middle school teacher, the respondent was more likely to 
TABLE 7: Frequencies and percentages by years teaching and leavers/stayers.

\begin{tabular}{|c|c|c|c|c|c|c|c|c|}
\hline \multirow{2}{*}{ Years Teaching } & \multicolumn{2}{|c|}{ Leaving } & \multirow{2}{*}{$\%$ within leave/stay } & \multicolumn{2}{|c|}{ Staying } & \multirow{2}{*}{$\%$ within leave/stay } & \multicolumn{2}{|c|}{ Total } \\
\hline & $f$ & $\%$ & & $f$ & $\%$ & & $f$ & $\%$ \\
\hline$<6$ & 143 & 9.1 & 27.6 & 186 & 11.9 & 17.8 & 329 & 21.0 \\
\hline $6-10$ & 155 & 9.9 & 29.9 & 238 & 15.2 & 22.8 & 393 & 25.1 \\
\hline $11-20$ & 156 & 10.0 & 30.1 & 361 & 23.1 & 34.6 & 517 & 33.1 \\
\hline$>20$ & 65 & 4.2 & 12.5 & 259 & 16.6 & 24.8 & 324 & 20.7 \\
\hline Total & 519 & 33.2 & 100.0 & 1044 & 66.8 & 100.0 & 1563 & 100.0 \\
\hline
\end{tabular}

TABLE 8: Frequencies and percentages by region and leavers/stayers.

\begin{tabular}{|c|c|c|c|c|c|c|c|c|}
\hline \multirow{2}{*}{ Region } & \multicolumn{2}{|c|}{ Leaving } & \multirow{2}{*}{$\%$ within leave/stay } & \multicolumn{2}{|c|}{ Staying } & \multirow{2}{*}{$\%$ within leave/stay } & \multicolumn{2}{|c|}{ Total } \\
\hline & $f$ & $\%$ & & $f$ & $\%$ & & $f$ & $\%$ \\
\hline New England & 23 & 1.5 & 4.4 & 57 & 3.6 & 5.4 & 80 & 5.1 \\
\hline Mid-Atlantic & 61 & 3.9 & 11.7 & 162 & 10.3 & 15.4 & 223 & 14.2 \\
\hline E N Central & 70 & 4.5 & 13.5 & 203 & 12.9 & 19.3 & 273 & 17.4 \\
\hline W N Central & 40 & 2.5 & 7.7 & 100 & 6.4 & 9.5 & 140 & 8.9 \\
\hline S Atlantic & 101 & 6.4 & 19.4 & 147 & 9.4 & 14.0 & 248 & 15.8 \\
\hline E S Central & 32 & 2.0 & 6.2 & 51 & 3.2 & 4.9 & 83 & 5.3 \\
\hline W S Central & 84 & 5.3 & 16.2 & 111 & 7.1 & 10.6 & 195 & 12.4 \\
\hline Mountain & 50 & 3.2 & 9.6 & 82 & 5.2 & 7.8 & 132 & 8.4 \\
\hline Pacific & 59 & 3.8 & 11.3 & 138 & 8.8 & 13.1 & 197 & 12.5 \\
\hline Total & 520 & 33.1 & 100.0 & 1051 & 66.9 & 100.0 & 1563 & 100.0 \\
\hline
\end{tabular}

be female. If the respondent was a minority, he/she was more likely to teach middle school than high school. The East North Central region had the highest percentage of high school teacher respondents, while the South Atlantic region had the highest percentage of middle school teacher respondents.

High school teachers were more likely to have a higher perception of their classroom control in textbook choice, teaching topics and techniques, grading, and assigning homework than middle school teachers. There were no significant differences in responses between the two groups in terms of administrative support.

\section{Summary}

The findings of this study provide insight into understanding why mathematics teachers are leaving the teaching profession. Almost one-third of the participants in this study indicated the intention to leave teaching in the next five years for reasons other than retirement. Results show that we are losing our youngest teachers, least-experienced teachers, and minority teachers at higher rates than other groups. Particular regions of the country are losing mathematics teachers at higher rates than other regions. Issues of classroom control and administrative support are significant factors in the decision to leave teaching.

Standards for teachers and schools are developed at the state and national levels. Most often, regulations and laws are handed down for teachers to implement, without teachers having any input into the legislation. Teachers in this study expressed the opinion that legislative decisions have hurt education and that some of the better ideas have lacked implementation. Many of the teachers expressed the opinion that they feel powerless to make changes and that no one cares what they think. Their perception is that the education system is broken and they would like teacher input included into legislative decision making.

Administrators play a key role in the atmosphere of a school. Feedback in this study from both new and experienced teachers indicated that the leadership of the principal and other administrators at the school was a major factor in their decision to leave teaching. Administrators should be given training so that they will have the skills necessary to work with and support all of their teachers. In many cases, the principal of a school has never been a classroom teacher or has taught at a grade level different from the school of leadership. Supporting administration in order to support teachers can make a major difference in teacher attrition rates.

Although several significant findings came from this research, further study must be done to target additional reasons for the attrition of our nation's mathematics teachers. In understanding more about this important issue, society and its leaders can form a partnership with teachers so that children can reap the benefit of obtaining a quality education. 
TABLE 9: Summary for the one-way analysis of variance (ANOVA) using the individual components of classroom control as the independent variables and leave/stay as the dependent variable.

\begin{tabular}{|c|c|c|c|c|c|}
\hline Source & Sum squares & df & Mean square & $F$ & $P$ \\
\hline \multicolumn{6}{|l|}{ Selecting textbooks } \\
\hline Between groups & 7.259 & 1 & 7.259 & 6.958 & $.008^{* *}$ \\
\hline Within groups & 1633.588 & 1566 & 1.043 & & \\
\hline Total & 1640.847 & 1567 & & & \\
\hline \multicolumn{6}{|l|}{ Selecting topics } \\
\hline Between groups & 7.010 & 1 & 7.010 & 6.598 & $.010^{*}$ \\
\hline Within groups & 1663.958 & 1566 & 1.063 & & \\
\hline Total & 1670.969 & 1567 & & & \\
\hline \multicolumn{6}{|l|}{ Selecting teach tech } \\
\hline Between groups & 1.673 & 1 & 1.673 & 4.161 & $.042 *$ \\
\hline Within groups & 629.597 & 1566 & .402 & & \\
\hline Total & 631.270 & 1567 & & & \\
\hline \multicolumn{6}{|l|}{ Evaluating students } \\
\hline Between groups & .918 & 1 & .918 & 2.346 & .126 \\
\hline Within groups & 613.875 & 1568 & .392 & & \\
\hline Total & 614.793 & 1569 & & & \\
\hline \multicolumn{6}{|l|}{ Disciplining students } \\
\hline Between groups & 1.703 & 1 & 1.703 & 3.522 & .061 \\
\hline Within groups & 758.388 & 1568 & .484 & & \\
\hline Total & 760.092 & 1569 & & & \\
\hline \multicolumn{6}{|c|}{ Amount of homework } \\
\hline Between groups & 1.180 & 1 & 1.180 & 3.768 & .052 \\
\hline Within groups & 491.113 & 1568 & .313 & & \\
\hline Total & 492.294 & 1569 & & & \\
\hline
\end{tabular}

* Significant at the $P<.05$ level.

** Significant at the $P<.01$ level.

\section{Appendix}

\section{Mathematics Teacher Retention Survey}

Code No.................

To what extent do you agree or disagree with each of the following statements? (Please circle the most appropriate response)

(1) During my first year of teaching, I received:

(a) reduced teaching schedule or number of preparations

(b) common planning time with other teachers

(c) seminars or classes for beginning teachers

(d) extra classroom assistance (teacher aides)

(e) regular supportive communication with principal/administration
Strongly Somewhat Somewhat Strongly

Agree Agree Disagree Disagree

Strongly Somewhat Somewhat Strongly

Agree Agree Disagree Disagree

Strongly Somewhat Somewhat Strongly

Agree Agree Disagree Disagree

Strongly Somewhat Somewhat Strongly Agree Agree Disagree Disagree

Strongly Somewhat Somewhat Strongly Agree Agree Disagree Disagree 
(2) I have control in my classroom in:

(a) selecting textbooks/instructional materials

(b) selecting content, topics, and skills to be taught

(c) selecting teaching techniques

(d) evaluating and grading students

(e) disciplining students

(f) determining the amount of homework assigned

(3) The school administrations' behavior toward the staff is supportive and encouraging

(4) I am satisfied with my teaching salary

(5) The level of student misbehavior in this school (such as noise, horse-play, or fighting in the halls, cafeteria) interferes with my teaching

(6) I worry about the security of my job because of the performance of my students on state and/or local tests

(7) I am generally satisfied with being a teacher at this school

(8) If I could go back to my college days and start over again, I would become a teacher

(9) Outside of my teaching career, I have a high degree of personal happiness

\begin{tabular}{|c|c|c|c|}
\hline Strongly & Somewhat & Somewhat & Strongly \\
\hline Agree & Agree & Disagree & Disagree \\
\hline rongly & Somewhat & on & Strongly \\
\hline Agree & Agree & Disa & Disagree \\
\hline Strongly & Somen & on & Strongly \\
\hline Agree & Agree & Disa & Disagree \\
\hline Strongly & Some & Son & Strongly \\
\hline Agree & Agree & Disa & Disagree \\
\hline Strongly & Som & $\mathrm{t}$ & Strongly \\
\hline Agree & Agree & Dis & Disagree \\
\hline Strongly & Som & $\mathrm{t}$ & igly \\
\hline Agree & Agr & Dis & Disagree \\
\hline Strongly & Som & $\mathrm{t}$ & gly \\
\hline Agree & Agr & Dis & Disagree \\
\hline Strongly & Som & $t$ & Strongly \\
\hline Agree & Agree & $\mathrm{D}$ & Disagree \\
\hline Strongly & Some & it & trongly \\
\hline Agree & Agree & Disą & Disagr \\
\hline Strongly & Som & & \\
\hline Agree & Agree & Disagre & Disagr \\
\hline Strongly & Som & Son & stiong \\
\hline Agree & Agree & Disagree & Disagr \\
\hline Strongly & Som & Sor & Str \\
\hline Agree & Agree & Disagree & Disagr \\
\hline Str & & & \\
\hline & Agree & ree & D \\
\hline
\end{tabular}

Please respond to the following questions:

(10) What is your current teaching assignment (Ex. 3 periods math, 2 periods science, 1 period P.E.)?

(11) How many years have you worked as a full time teacher in public schools?

(12) How many years have you taught mathematics at:

Middle School ...... High School ......

(13) Did you enter teaching through an alternative certification program?

...... Yes...... No

(14) Are you a Highly Qualified Teacher according to your state's requirements?

...... Yes...... No 
(15) In your first year of teaching, did you participate in a teacher induction program?

...... Yes...... No

(16) Your student class sizes are typically:

..... less than 21 students ..... 21-30 students ..... 31+ students

(17) What are the reasons you became a teacher? (Please check all that apply):

..... like working with young people ..... working conditions ...... salary

..... personal fulfillment ..... professional status ..... power

..... good career if you have children ..... help others/make a difference ..... benefits

...... influence of role model/teacher ...... parent/family encouragement ...... holidays/vacations

...... Other (please specify)

(18) Gender:...... Male ...... Female

(19) Age:

(20) Ethnicity:

...... African-American/Black ...... American Indian/Alaska Native

...... Asian ..... Latino/Hispanic

..... Native Hawaiian/other Pacific Islander ...... White/non-Hispanic

...... Other

(21) School Enrollment:

..... less than $100 \ldots$... 101-500 .... 501-1000 .... 1001-2000 ..... Over 2000

(22) In what state do you teach:

(23) How many more years do you see yourself teaching mathematics?

(24) If you plan to leave the teaching profession, please share your reason(s) why:

(25) Would you be willing to be contacted for an interview? ..... Yes ..... No

If yes, please provide contact information (i.e., phone number or email address):

(26) Would you like a copy of the results of this study? If so, please provide your email address:

Thank you for taking time to participate in this study.

Your responses are greatly appreciated!!!

\section{References}

[1] A. Levy, E. Fields, and E. Jablonski, "Overview of research: What we know and don't know about the consequences of science and math teacher turnover," Paper presented at the National Commission on Teaching and America's Future, Racine, Wis, USA, October 2006, http://ltd.edc.org/science.

[2] G. Hampden-Thompson, W. Herring, and G. Kienzi, Attrition of public school mathematics and science teachers. NCES Report No. 2008-77, 2008, http://eric.ed.gov/PDFS/ ?ED501286.pdf.

[3] R. Ingersoll and D. Perda, The Mathematics and Science Teacher Shortage: Fact and Myth, Consortium for Policy Research in Education, Philadelphia, Pa, USA, 2009.

[4] R. Ingersoll and L. Merrill, "Who's teaching our children?" Association for Supervision and Curriculum Development, vol. 67, no. 8, pp. 14-20, 2010.

[5] R. Ingersoll, Who Controls Teachers' Work? Power and Accountability in America's Schools, Harvard University Press, Cambridge, MA, USA, 2006.

[6] J. Dewey, The Child and the Curriculum, University of Chicago Press, Chicago, Ill, USA, 1974.
[7] E. Durkheim, Moral Education: A Study in the Theory and Application of the Sociology of Education, Free Press, New York, NY, USA, 1961.

[8] J. Meyer and W. Scott, Organizational Environments: Ritual and Rationality, Sage, Beverly Hills, Calif, USA, 1983.

[9] L. Darling-Hammond, "Inequality and the right to learn: access to qualified teachers in California's public schools," Teachers College Record, vol. 106, no. 10, pp. 1936-1966, 2004.

[10] M. Cochran-Smith, "Inequality and the right to learn: access to qualified teachers in California's public schools," Journal of Teacher Education, vol. 55, no. 5, pp. 367-392, 2004.

[11] L. Darling-Hammond, "We need to invest in math and science teachers," Chronicle of Higher Education, vol. 54, no. 17, p. 1, 2007.

[12] R. Ingersoll, Misdiagnosing the Teacher Quality Problem, The Consortium for Policy Research in Education, Philadelphia, Pa, USA, 2007.

[13] K. Futernick, A Possible Dream: Retaining California Teachers so All Students Learn, California State University Press, Sacramento, Calif, USA, 2007.

[14] J. Marvel, D. Lyter, P. I. Peltola, G. Strizek, B. Morton, and R. Rowland, Teacher attrition and mobility: Results from the 2004-2005 teacher follow-up survey, (NCES 2007-307), 
Washington, DC, USA, National Center for Education Statistics, 2006.

[15] C. M. Guarino, L. Santibañez, and G. A. Daley, "Teacher recruitment and retention: a review of the recent empirical literature," Review of Educational Research, vol. 76, no. 2, pp. 173-208, 2006.

[16] X. S. Liu, "The effect of teacher influence at school on firstyear teacher attrition: a multilevel analysis of the Schools and Staffing Survey for 1999-2000," Educational Research and Evaluation, vol. 13, no. 1, pp. 1-16, 2007.

[17] Center for Teaching Quality, "Understanding teacher working conditions: a review and look to the future," 2008, http://www.teachingquality.org/pdfs/TWC2_Nov08.pdf.

[18] C. N. Tsouloupas, R. L. Carson, R. Matthews, M. J. Grawitch, and L. K. Barber, "Exploring the association between teachers' perceived student misbehaviour and emotional exhaustion: the importance of teacher efficacy beliefs and emotion regulation," Educational Psychology, vol. 30, no. 2, pp. 173-189, 2010.

[19] S. Kukla-Acevedo, "Leavers, movers, and stayers: the role of workplace conditions in teacher mobility decisions," Journal of Educational Research, vol. 102, no. 6, pp. 443-452, 2009.

[20] J. Buchanan, "Where are they now? Ex-teachers tell their lifework stories," Issues in Educational Research, vol. 19, no. 1, pp. $1-13,2009$.

[21] D. Hare and J. Heap, Effective Teacher Recruitment and Retention Strategies in the Midwest: Who is Making Use of Them? North Central Regional Educational Laboratory, Napierville, Canada, 2001.

[22] Charlotte Advocates for Education, "Role of principal leadership in increasing teacher retention. Creating a supportive environment," 2004, http://sparkaction.org/node/26467.

[23] A. Miller, "Principal turnover, student achievement and teacher retention. (Unpublished master's thesis)," Princeton University, Princeton, NJ, USA, 2009.

[24] K. Brown and S. Wynn, "Finding, supporting, and keeping: the role of the principal in teacher retention issues," Leadership and Policy in Schools, vol. 8, pp. 37-63, 2009.

[25] E. Denton, “Teachers' perceptions of how leadership styles and practices of principals influence their job satisfaction and retention," Dissertation Abstracts International: Section A. Education, vol. 70, no. 08, 3369249, 2009.

[26] National Center for Education Statistics, "Schools and staffing survey, 2007-2008," 2008, http://nces.ed.gov/surveys/ sass/pdf/0708/sass4a.pdf.

[27] United States Census Bureau, Census regions and divisions of the United States, 2010, http://www.census.gov/geo/ www/us_regdiv.pdf. 

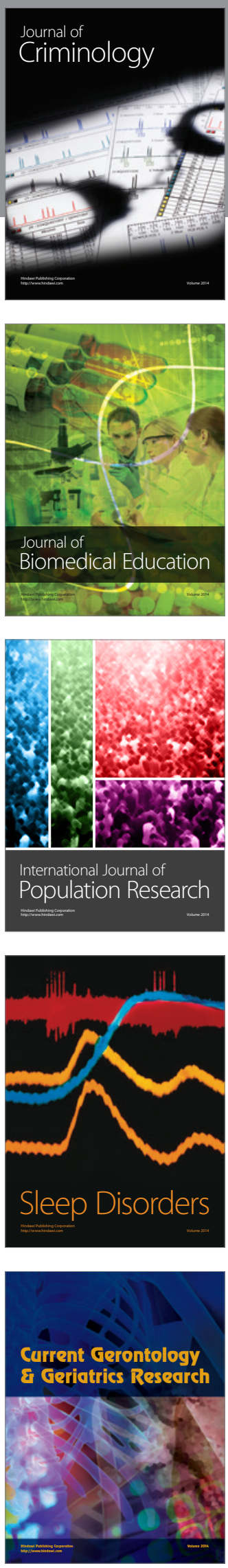
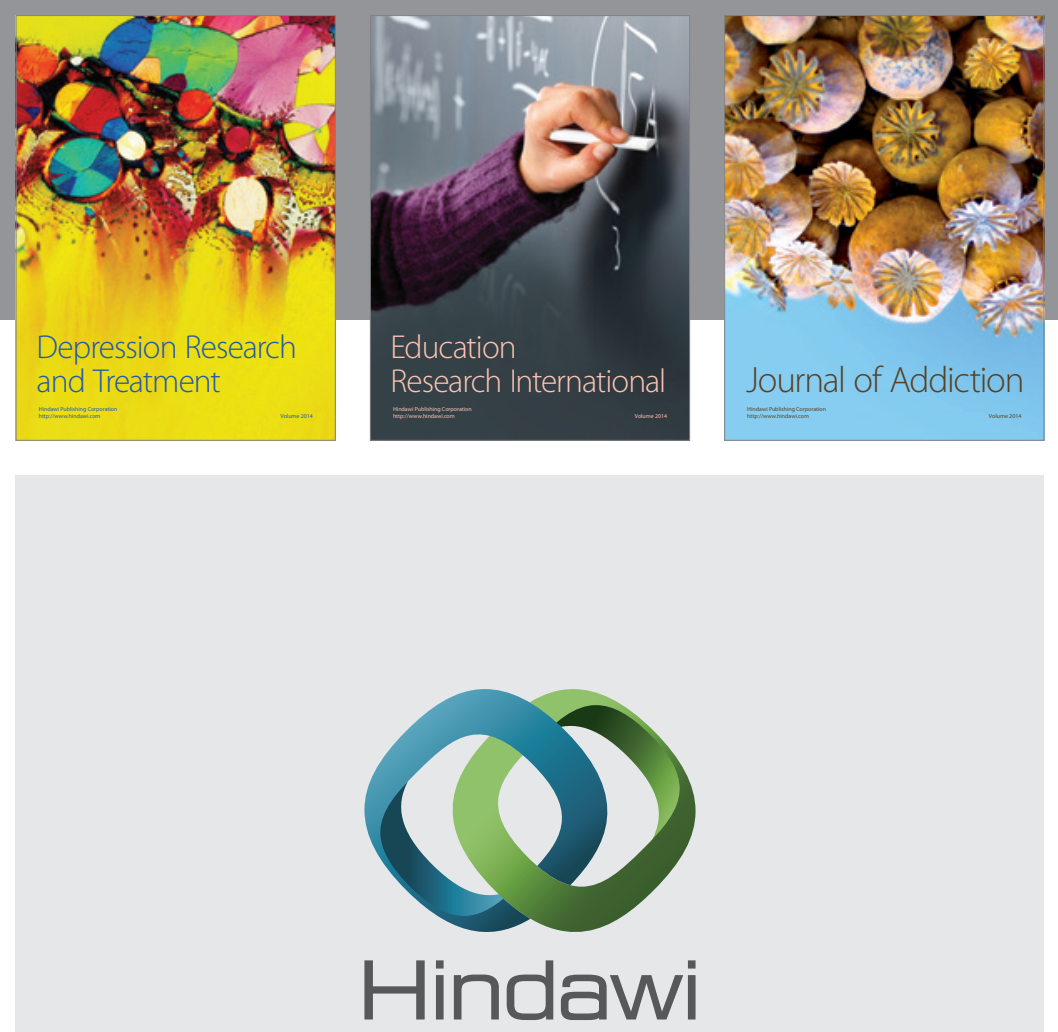

Submit your manuscripts at

http://www.hindawi.com

Child Development Research
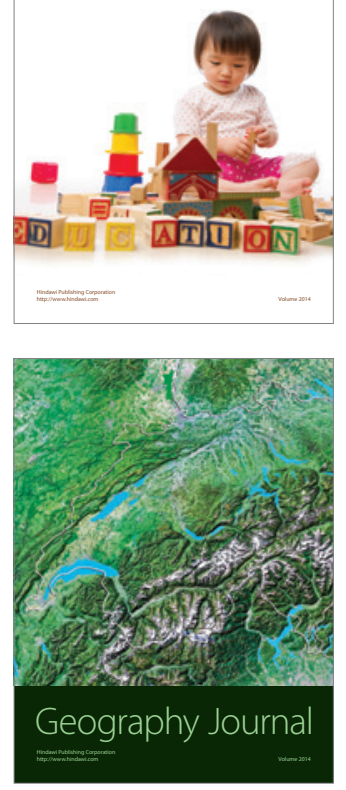

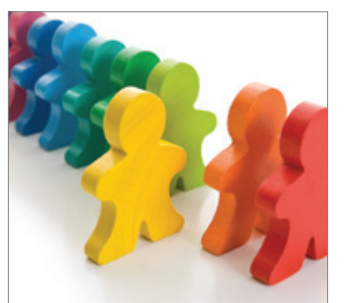

Autism

Research and Treatment
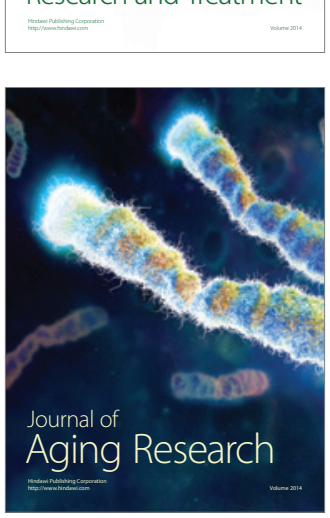
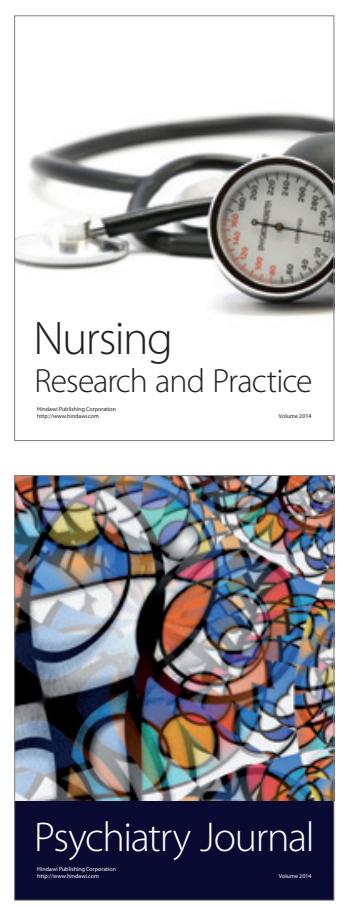
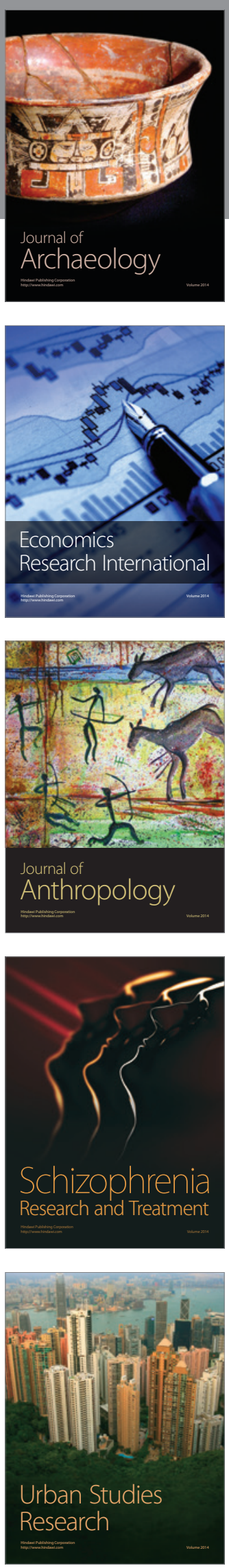